\title{
Molecular Evidence for the Association of Swarm Forming Desert Locust, Schistocerca gregaria gregaria (Forskål) in Pakistan with Highly Prevalent Subspecies in Sahara Desert of Africa
}

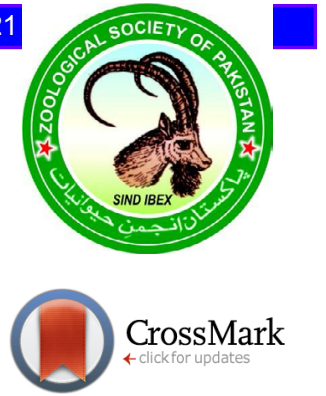

\author{
Jam Nazeer Ahmad ${ }^{1, *}$, Samina J.N. Ahmad ${ }^{1,2, *}$, Mubashir Ahmad Malik ${ }^{1}$, Abid Ali ${ }^{1}$, \\ Muhammad Ali ${ }^{3}$, Ejaz Ahmad ${ }^{1}$, Muhammad Tahir ${ }^{2}$ and Muhammad Ashraf ${ }^{2}$ \\ ${ }^{\prime}$ Department of Entomology, University of Agriculture, Faisalabad \\ ${ }^{2}$ Plant Stress Physiology and Molecular Biology Laboratory, Department of Botany, \\ University of Agriculture, Faisalabad \\ ${ }^{3}$ Institute of Agricultural Sciences, University of the Punjab, Quaid-e-Azam Campus \\ Lahore
}

\begin{abstract}
A B S T RA C T
Locust commonly known as short horned grasshopper is one of the most dangerous agricultural pests worldwide. There are various important species of large swarms forming of desert locusts found in different regions of the world. In early 2020, in Pakistan, huge swarm of desert locust infestation was observed in different provinces of Pakistan. Precise and correct identification of any pest is very important to start a proper control strategy against it. The current study was conducted to identify and characterize locust species and to determine their association with other swarm forming locust species worldwide. Morphological features and molecular characters were observed using digital camera and PCR technique, respectively. For molecular identification, DNA was extracted through CTAB method and polymerase chain reaction was performed using mitochondrial cytochrome oxidase I (COI) gene based primers. Gel electrophoresis of the PCR products of desert locusts indicated a 710bp amplified DNA fragment on $1.5 \%$ agarose gel. DNA sequence analysis of PCR product indicated that specimens shared a 99$100 \%$ identity with Schistocerca gregaria gregaria) (Forskål, 1775). Molecular phylogenetic analysis and evolutionary divergence study also revealed the formation of same cluster in phylogenetic tree with that of specific subspecies $S$. g. gregaria which further deviate genetically not only from closely related subspecies (S. g. flaviventris) but also other species reported from various countries. Migratory pattern of S. g. gregaria from Africa to Asia and neighboring countries with their potential routes also suggested developing sustainable policy to counter internal as well as external threat. This is the first report of molecular identification of $S$. g. grgaria and its association with most prevailed subspecies of Sahara desert in Northern Africa. Desert locust, S. g. gregaria is very destructive polyphagus pest therefore, immediately; control measures should be adopted to stop its further spread and infestation in Pakistan.
\end{abstract}

\begin{tabular}{l} 
Article Information \\
\hline Received 01 May 2020 \\
Revised 30 July 2020 \\
Accepted 18 August 2020 \\
Available online 11 September 2020 \\
Authors' Contribution \\
JNA, EA and MAM planned the \\
experiments and collected insects. \\
JNA, EA and MT performed \\
experiments. SJNA, JNA and EA \\
wrote the manuscript. M Ashraf \\
presented the research idea and gave \\
guidance. AA, M Ali collected locust \\
sampling from all over Pakistan. \\
Key words \\
Desert locust, Shistocerca gregaria \\
gregaria, PCR, Molecular phylogeny, \\
DNA barcoding.
\end{tabular}

\section{INTRODUCTION}

$\mathrm{T}$ he desert locust, Schistocerca gregaria (Orthoptera: Acrididae), are distributed all over the world and are commonly known as short horned grasshoppers. It has severely damaged vegetation found in eastern and western hemisphere (Harvey, 1981; Song, 2004; Lovejoy et al., 2006; Cheseto et al., 2015). Similar to other locust species, $S$. gregaria undergoes phase polyphenism under density stress and crowding inducing two phenotypic phases, solitarious and gregarious (Uvarov, 1977). In the last two centuries, its gregarious phase had destroyed vegetation

\footnotetext{
* Corresponding authors: jam.ahmad@uaf.edu.pk; saminatmalik@yahoo.com 0030-9923/2020/0006-2233 \$ 9.00/0

Copyright 2020 Zoological Society of Pakistan
}

in Southwest Asia, Africa and Middle East (Meinzingen, 1993; El Hassan, 2000). The desert locust undergoes incomplete metamorphosis forming egg, nymph and adult. Both nymph and adult of locust show density dependent phase polymorphism. Gregarious individuals have black and orange color while cryptic and solitary's locusts have green to brown color depending on ecological conditions (Pener, 1991; Tanaka, 2006; Ayali, 2019). There are more than 700 species of locusts including 50 species in the genus Schistocerca where four species $S$. gregaria, $S$. piceifrons, $S$. cancellata and $S$. interrita form swarms, the remaining Schistocerca species are sedentary grasshopper (Song and Wenzel, 2008; Song et al., 2017). The desert locust, $S$. gregaria has two sub species, a phase changing species ( $S$. gregaria gregaria) having largest expansive swarm zone found in Northern Africa whereas solitarious species (S. gregaria flaviventris) prevailed in Southern 
Africa that rarely undergoes phase changing (Popov et al., 1991; Chapuis et al., 2017). Central American locust (S. piceifrons) has a long history as a pest, and has even been implicated in the downfall of the Mayan civilization (Granados, 2011). It has two subspecies; $S$. p. piceifrons found in Mexico and parts of Central America while the other (S. p. peruviana) present in Peru, Ecuador, Colombia, Venezuela, Panama, Trinidad and Tobago (Harvey, 1983; Barrientos et al., 1992). South American locust (S. cancellata) damage was reported first time on cassava in 1538 in Buenos Aires (Gastón, 1969), then spread to Argentina infesting many plants including soybeans, sorghum, maize, peanut, and citrus, as well as pasture grass. Migratory locusts (Locusta migratoria) are the most widely distributed grasshopper species in the world based on their geographic range corresponding to the Asian migratory locust (L. migratoria migratoria) and the African migratory locust, (L. migratoria migratorioides) (Ma et al., 2012). Asian migratory locust that can fly $1000 \mathrm{~km}$ is one of the most important agricultural pests in Russia, Kazhakhstan, and Uzbekistan (Latchininsky, 2013), China (Stige et al., 2007; Tian et al., 2011) and Australia (Farrow, 1979). Pakistan is an agricultural country and crops are attacked by a number of pests including lepidopteron, dipterous and coleopterans. Pakistan is also an important front-line country for locust because it has summer and spring breeding areas such as the Indian border in the deserts of Tharparkar, Khipro and Cholistan (Sindh and Southern Punjab) and Lasbela/Uthal area west of Karachi considered as a transition zone where locusts may be present nearly any time of year. After the first swarm which occurred in 1961, a large swarm arrived in Pakistan from Iran ravaging cotton, wheat, maize and other crops in 1961. Then in November 2019, a swarm was seen in Karachi which spread to other regions of Pakistan. On February 1, 2020, Government of Pakistan declared a national emergency to protect crops and help farmers. There are different species of locusts that found in different parts of the world. It is utmost important to identify accurate species for its proper control and management. DNA barcoding is widely implemented and a popular molecular technique to identify species from a small portions of cytochrome oxidase I (COI) gene (Manzoor et al., 2018). The author has recently identified and characterized based on molecular technique several important insect pests and pathogens (Ahmad et al., 2017, 2019; Manzoor et al., 2018, 2020; Sharif et al., 2019). The objective of the present study was to identify, characterize and provide phylogenetic analysis of the population of desert locust farming swarms in Pakistan so that their association with the known species existed in different countries of the world could be revealed on the basis of mitochondrial cytochrome oxidase I (COI) gene.

\section{MATERIALS AND METHODS}

Samples collection and PCR amplification of $\mathrm{COI}$ gene

During a survey in late 2019 and early 2020, hand collection of adult locust was done from different regions of Pakistan and were preserved in $96 \%$ alcohol or stored at $-20{ }^{\circ} \mathrm{C}$ in a freezer for molecular study. Total genomic DNA from the legs of the collected locust was extracted using $\mathrm{CTAB}$ method. The quantification of DNA was done using Pico drop micro volume spectrophotometer (Pico200, UK). PCR amplifications were performed in PCR machine (PeqSTAR, Germany) with primer pairs LCO-1490 (5'-TCTCAACAAACCATAAGGACATTGG-3' andHCO2198 (5'-TAAACTTCTGGGTGTCCAAAGAATCA-3') (Folmer et al., 1994). The $25 \mu 1$ PCR reaction mixture was prepared using 50-100 ng quantity of each DNA sample, $10 \mathrm{mM}$ of each forward and reverse Primers and PCR master Mix according to mentioned protocol. The DNA fragments of $710 \mathrm{bp}$ were obtained following PCR condition; first an initial denaturation temperature of $95^{\circ} \mathrm{C}$ for $5 \mathrm{~min}$. was conducted. Then denaturation temperature of $94^{\circ} \mathrm{C}$ for $40 \mathrm{sec}$., annealing temperature of $47^{\circ} \mathrm{C}$ for 40 sec. and an extension temperature of $72^{\circ} \mathrm{C}$ for $45 \mathrm{~min}$. was carried out for 34 cycles. The final extension temperature was used at $72^{\circ} \mathrm{C}$ for $7 \mathrm{~min}$. The amplified PCR products (710bp) were visualized using gel electrophoresis on 1.5\% agarose gel.

\section{Sequencing and analysis}

The 710bp PCR products were sequenced directly in both directions using services by Macrogen (South Korea). Obtained sequences were analyzed using Lasergene v. 7.1 software package (DNASTAR, USA) and further aligned using CLUSTAL W method of Bio-Edit software. Comparison of obtained sequences with sequences available in GenBank was accomplished using BLASTn service available at http://www.ncbi.nlm.nih.gov:80/BLAST. The studies were performed with software BLASTN 2.8.0+ employing a methodology for Pairwise Alignment for the construction of phylogenetic tree. Mview of aligned sequences were obtained by using CLUSTAL Omega alignment software. Homology phylogenetic studies were also performed with MEGA6 software employing a methodology named as "Maximum Likelihood method" (Tamura et al., 2013). Analyses of evolutionary estimates (Zuckerkandl and Pauling, 1965) were conducted using the Poisson correction model. The analysis involved 27 amino acid sequences. All positions containing gaps and missing data were eliminated. There were a total of 658 positions in the final dataset. Evolutionary analyses were conducted in MEGA6 (Tamura et al., 2013). 


\section{RESULTS AND DISCUSSION}

Sequence alignment and phylogenetic analysis

The alignments of sequenced nucleotides of $710 \mathrm{bp}$ were done with a multiple sequence alignment tool. The nucleotides sequences of $S$. g. gregaria from Pakistan submitted at National Centre of Biotechnology Information (NCBI) site with accession numbers (MK168615.1, MK168616.1, MT449731.1, MT449732.1, MT449733.1, MT449734.1, MT449735.1, KU2514651.1) showed 100\% similarity to $S$. g. gregaria (KU251463.1, KY980902.1) and $>99 \%<100 \%$ to KU251464.1, KU251465.1, KU251462.1 of NCBI sequences of $S$. g. gregaria reported from North Africa. Further analysis indicated $93-95 \%$ genetic similarity of South American locust, S. cancellata (GU115922.1) and Central American locust, S. piceifron (GU116453.1), S. americana (GU122627.1), S. impleta (GU115862.1) and S. guisqueya (GU115949.1) as well as some other species (GU115864.1, GU115863.1, GU115867.1, GU115915.1, and KM243977.1) (Table I). Similarly, pair wised aligned DNA sequences of $S$. g. gregaria from Pakistan, showed > 99-100\% genetic similarity with same subspecies reported from Mauritania (KU251463.1) except migratory locust (AB497251.1) showing 88\% similarity (Fig. 1). Molecular phylogenetic tree produced (Maximum Likelihood Method) from the DNA sequences available at NCBI showed that studied sequences of the desert locust from Pakistan (MK168615.1, MK168616.1, MT449731.1, MT449732.1, MT449733.1, MT449734.1, MT449735.1, KU2514651.1) formed same cluster with the same species of desert locust, $S$. g. gregaria isolates reported from the countries of Northern Africa (Mauritania11, Niger7, Algeria19) and different clusters were observed with the different species of locusts reported from Southern Africa, Central and South America following distinctive mono clade with closely related subspecies of desert locust (S.gregaria flaviventris) (Fig. 2). Similarly, in estimation of evolutionary divergences, amino acid substitution between sequences of different and same species indicated very little divergence values (0.000-0.009) between same species while it increased trend was observed in different species (0.012-0.207) with maximum divergence value (0.207) in migratory locust (Locusta migratoria) (Table II). The results of current study showed that the studied DNA sequences of desert locusts from Pakistan belonged to the most prevailed subspecies of desert locust, Schistocerca gregaria gregaria.

Table I.- BLASTnt results of DNA sequences of locusts submitted on NCBI showing their Identity \% of species of desert locusts from Pakistan, $S$. g. gregaria with various important species reported from other countries of the World.

\begin{tabular}{lcccccc}
\hline Query / Subject & Max score & Total score & Query coverage & E. value & Identity & Accessions \\
\hline MT449735.1 & & & & & & \\
Schistocerca gregaria gregaria Pak1 & 1216 & 1216 & $100 \%$ & 0.0 & $100.00 \%$ & MT168616.1 \\
S. g. gregaria mau11 & 1216 & 1216 & $100 \%$ & 0.0 & $100.00 \%$ & KU251463.1 \\
S. g. gregaria & 1216 & 1216 & $100 \%$ & 0.0 & $100.00 \%$ & KY980902.1 \\
S. g. gregaria Nig7 & 1199 & 1199 & $100 \%$ & 0.0 & $99.54 \%$ & KU251464.1 \\
S. g. gregaria pak2 & 1194 & 1194 & $100 \%$ & 0.0 & $99.39 \%$ & MT168616.1 \\
S. g. gregaria pak3 & 1194 & 1194 & $100 \%$ & 0.0 & $99.39 \%$ & KU251465.1 \\
S. g. gregaria Alg19 & 1188 & 1188 & $100 \%$ & 0.0 & $99.34 \%$ & KU251462.1 \\
S. g. flaviventris & 1194 & 1194 & $100 \%$ & 0.0 & $98.79 \%$ & KU251470.1 \\
S. g. flaviventris & 1194 & 1194 & $100 \%$ & 0.0 & $98.12 \%$ & KU251474.1 \\
S. americana & 1055 & 1055 & $100 \%$ & 0.0 & $95.59 \%$ & GU122627.1 \\
S. impleta & 1044 & 1044 & $100 \%$ & 0.0 & $95.29 \%$ & GU115862.1 \\
S. guisqueya & 1038 & 1038 & $100 \%$ & 0.0 & $95.14 \%$ & GU115949.1 \\
S. melanocera & 1033 & 1033 & $100 \%$ & 0.0 & $94.98 \%$ & GU115864.1 \\
S. literosa & 1033 & 1033 & $100 \%$ & 0.0 & $94.98 \%$ & GU115863.1 \\
S. guisqueya & 1022 & 1022 & $100 \%$ & 0.0 & $94.68 \%$ & GU115867.1 \\
S. pallens & 1022 & 1022 & $100 \%$ & 0.0 & $94.68 \%$ & GU115915.1 \\
S. cancellata & 1016 & 1016 & $100 \%$ & 0.0 & $94.53 \%$ & GU 116453.1 \\
S. piceifrons & 1014 & 1014 & $99 \%$ & 0.0 & $94.52 \%$ & GU 115922.1 \\
S. lineata & 1000 & 1000 & $100 \%$ & 0.0 & $93.92 \%$ & KM 243977.1 \\
L. migratoria & 1000 & 1000 & $100 \%$ & 0.0 & $88.92 \%$ & AB497251.1 \\
\hline
\end{tabular}




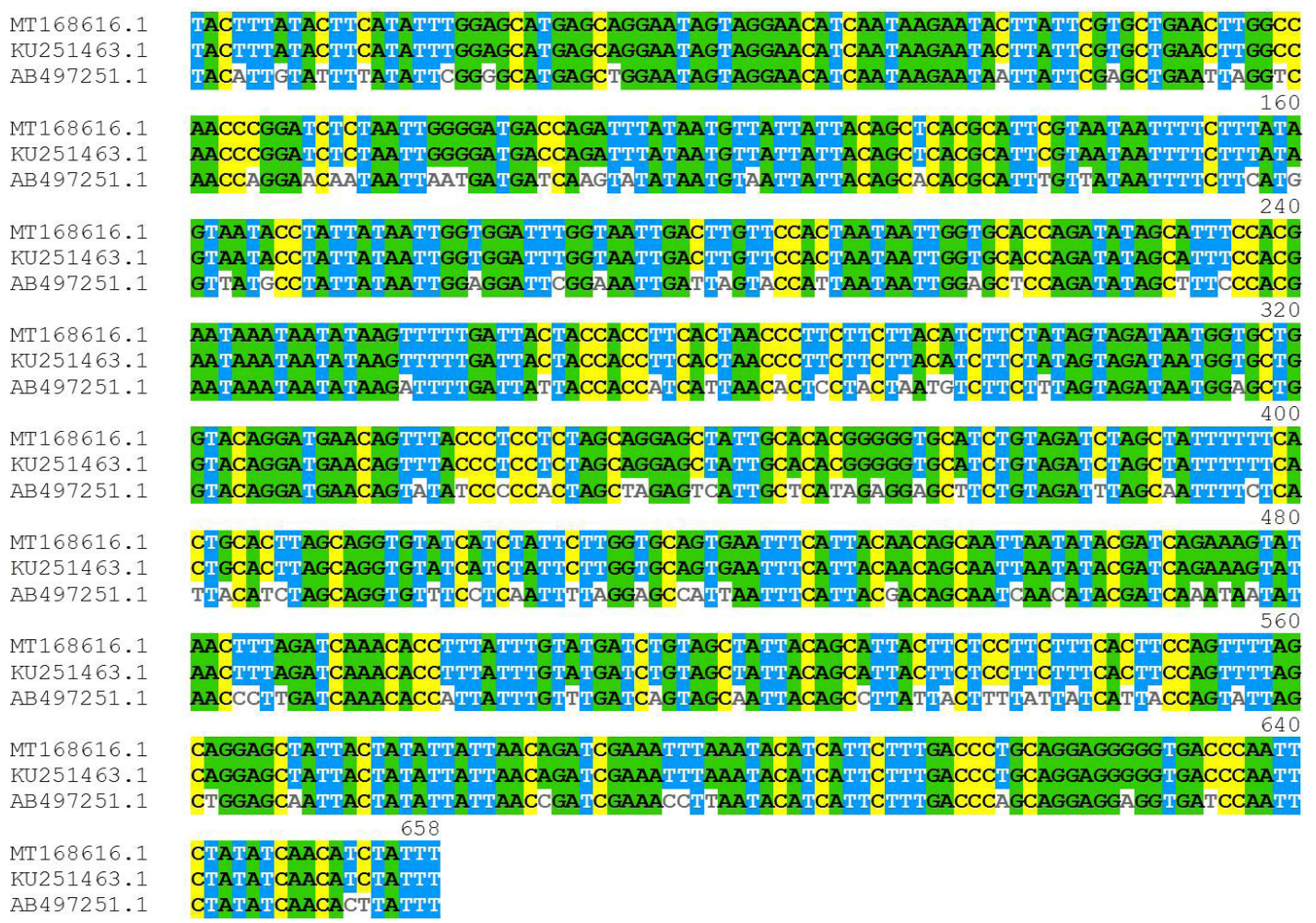

Fig. 1. Molecular alignment by Clustal Omega from sequenced DNA of desert locust, S. gregaria gregaria from Pakistan (MT168616.1 SG-BKR2); and S. gregaria gregaria from foreign country (KU251463.1) and Locusta migratoria (AB497251.1) based on mitochondrial Cytochrome oxidase I gene based primers.

Table II.- Estimates of Evolutionary Divergence between Sequences.

\begin{tabular}{|c|c|c|c|c|c|c|c|c|c|c|c|c|c|c|c|c|c|c|c|c|c|c|c|c|c|c|c|}
\hline & 1 & 2 & 3 & 4 & 5 & 6 & 7 & 8 & 9 & 10 & 11 & 12 & 13 & 14 & 15 & 16 & 17 & 18 & 19 & 20 & 21 & 22 & 23 & 24 & 25 & 26 & 27 \\
\hline \multicolumn{28}{|l|}{ MT449731.1 S.g.gregaria } \\
\hline MT168615.1 S.g.gregaria & 0.008 & & & & & & & & & & & & & & & & & & & & & & & & & & \\
\hline MT449732.1 S.g.gregaria & 0.008 & 0.000 & & & & & & & & & & & & & & & & & & & & & & & & & \\
\hline MT449733.1 S.g.gregaria & 0.008 & 0.000 & 0.000 & & & & & & & & & & & & & & & & & & & & & & & & \\
\hline MT449734.1 S.g.gregaria & 0.000 & 0.008 & 0.008 & 0.008 & & & & & & & & & & & & & & & & & & & & & & & \\
\hline MT449735.1 S.g.gregaria & 0.000 & 0.008 & 0.008 & 0.008 & 0.000 & & & & & & & & & & & & & & & & & & & & & & \\
\hline KY980902.1 S.g.gregaria & 0.009 & 0.002 & 0.002 & 0.002 & 0.009 & 0.009 & & & & & & & & & & & & & & & & & & & & & \\
\hline KU251463.1 S.g.gregaria & 0.008 & 0.000 & 0.000 & 0.000 & 0.008 & 0.008 & 0.002 & & & & & & & & & & & & & & & & & & & & \\
\hline KU251470.1 S.g.flaviventris & 0.012 & 0.005 & 0.005 & 0.005 & 0.012 & 0.012 & 0.0060 & 0.005 & & & & & & & & & & & & & & & & & & & \\
\hline KU251464.1 S.g.gregaria & 0.003 & 0.005 & 0.005 & 0.005 & 0.003 & 0.003 & 0.0060 & 0.005 & 0.009 & & & & & & & & & & & & & & & & & & \\
\hline MT168616.1 S.g.gregaria & 0.002 & 0.006 & 0.006 & 0.006 & 0.002 & 0.002 & 0.0080 & 0.006 & 0.011 & 0.002 & & & & & & & & & & & & & & & & & \\
\hline KU251474.1 S.g.flaviventris & 0.014 & 0.006 & 0.006 & 0.006 & 0.014 & 0.014 & 0.0080 & 0.006 & 0.002 & 0.0110 & 0.012 & & & & & & & & & & & & & & & & \\
\hline KU251465.1 S.g.gregaria & 0.005 & 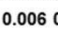 & 0.006 & 0.006 & 0.005 & 0.005 & 0.0080 & 0.006 & 0.011 & 0.0020 & 0.003 & 0.012 & & & & & & & & & & & & & & & \\
\hline KU251462.1 S.g.gregaria & 0.003 & 0.008 & 0.008 & 0.008 & 0.003 & 0.003 & 0.0090 & 0.008 & 0.012 & 0.0030 & 0.005 & 0.014 & 40.005 & & & & & & & & & & & & & & \\
\hline GU122627.1 S.americana & 0.051 & 0.045 & 0.045 & 0.045 & 0.051 & 0.051 & 0.0470 & 0.045 & 0.050 & 0.0480 & 0.050 & 0.051 & 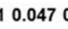 & 0.051 & & & & & & & & & & & & & \\
\hline GU115926.1 S.impleta & 0.050 & $0.047 \mathrm{C}-3 \mathrm{c}-\mathrm{c}$ & 0.047 & 0.047 & 0.050 & 0.050 & 0.0480 & 0.047 & 0.051 & 0.0470 & 0.048 & 0.053 & $30.045 c$ & 0.050 & 0.043 & & & & & & & & & & & & \\
\hline GU115949.1 S.quisqueya & 0.056 & 0.050 & 0.050 & 0.050 & 0.056 & 0.056 & 0.0510 & 0.050 & 0.055 & 0.0530 & 0.055 & 0.056 & $60.0510-3-20$ & 0.056 & 0.032 & 20.039 & & & & & & & & & & & \\
\hline GU115864.1 S.melanocera & 0.051 & 0.051 & 0.051 & 0.051 & 0.051 & 0.051 & 0.0530 & 0.051 & 0.056 & 0.0510 & 0.053 & 0.058 & 80.050 & 0.051 & 0.047 & 0.0120 & 0.045 & & & & & & & & & & \\
\hline GU115863.1 S.literosa & 0.055 & 0.051 & 0.051 & 0.051 & 0.055 & 0.055 & 0.0530 & 0.051 & 0.056 & 0.0510 & 0.053 & 0.055 & 50.050 & 0.055 & 0.047 & 0.0090 & 0.039 & 0.009 & & & & & & & & & \\
\hline GU115867.1 S.quisqueya & 0.061 & 0.055 & 0.055 & 0.055 & 0.061 & 0.061 & 0.0560 & 0.055 & 0.059 & 0.0580 & 0.059 & 0.061 & 10.056 & 0.061 & 0.040 & 0.0430 & 0.008 & 0.0500 & 0.043 & & & & & & & & \\
\hline GU115915.1 S.pallens & 0.056 & $0.055 \mathrm{C}-2 \mathrm{c}-\mathrm{c}$ & 0.055 & 0.055 & 0.056 & 0.056 & 0.0560 & 0.055 & 0.059 & 0.0530 & 0.055 & 0.058 & 80.0510 & 0.056 & 0.051 & 0.0090 & 0.045 & 0.0120 & 0.006 & 0.050 & & & & & & & \\
\hline KM243977.1 S.lineata & 0.071 & 0.064 & 0.064 & 0.064 & 0.071 & 0.071 & 0.0640 & 0.064 & 0.069 & 0.0680 & 0.069 & 0.071 & 10.0660 & 0.071 & 0.053 & 30.0370 & 0.050 & 0.0370 & 0.037 & 0.055 & 0.042 & & & & & & \\
\hline GU115965.1 S.cancellata & 0.081 & 0.074 & 0.074 & 0.074 & 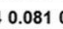 & 0.081 & 0.0760 & 0.074 & 0.079 & 0.0770 & 0.079 & 0.081 & 0.0760 & 0.081 & 0.063 & 30.0580 & 0.066 & 0.0580 & 0.058 & 0.071 & 0.063 & 0.058 & & & & & \\
\hline GU115869.1 S.cancellata & 0.072 & 0.066 & 0.066 & 0.066 & 0.072 & 0.072 & 0.0680 & 0.066 & 0.071 & 0.0690 & 0.071 & 0.072 & 20.0680 & 0.072 & 0.050 & 0.0500 & 0.053 & 0.0510 & 0.050 & 0.061 & 0.055 & 0.051 & 0.017 & & & & \\
\hline GU115923.1 S.piceifrons & 0.068 & 0.061 & 0.061 & 0.061 & 0.068 & 0.068 & 0.0630 & 0.061 & 0.066 & 0.0640 & 0.066 & 0.068 & 30.0630 & 0.068 & 0.045 & 50.0550 & 0.053 & 0.0550 & 0.053 & 0.061 & 0.058 & 0.053 & 0.055 & 0.040 & & & \\
\hline GU115861.1 S.piceifrons & 0.064 & 0.058 & 0.058 & 0.058 & 0.064 & 0.064 & 0.0590 & 0.058 & 0.063 & 0.0610 & 0.063 & 0.064 & 40.0590 & 0.064 & 0.043 & 30.0480 & 0.045 & 0.0500 & 0.048 & 0.053 & 0.053 & 0.047 & 0.047 & 0.032 & 0.009 & & \\
\hline AB497251.1 L. migratoria & 0.199 & 0.199 & 0.199 & 0.199 & 0.199 & 0.199 & 0.2010 & 0.199 & 0.203 & 0.1990 & 0.201 & 0.205 & 50.1990 & 0.199 & 0.205 & 50.1900 & 0.183 & 0.1880 & 0.190 & 0.185 & 0.192 & 0.181 & 0.176 & 0.187 & 0.207 & 0.201 & \\
\hline
\end{tabular}

The number of amino acid substitutions per site from between sequences is shown. Divergences values are very small between same species and increases as DNA of different species diverged more. Pakistani isolates (MK168615.1, MK168616.1, MT449731.1, MT449732.1, MT449733.1, MT449734.1, MT449735.1, and KU2514651.1) compared with DNA sequences of same or different species reported from other countries. Name of locust species (left) and evolutionary divergence value (right). 


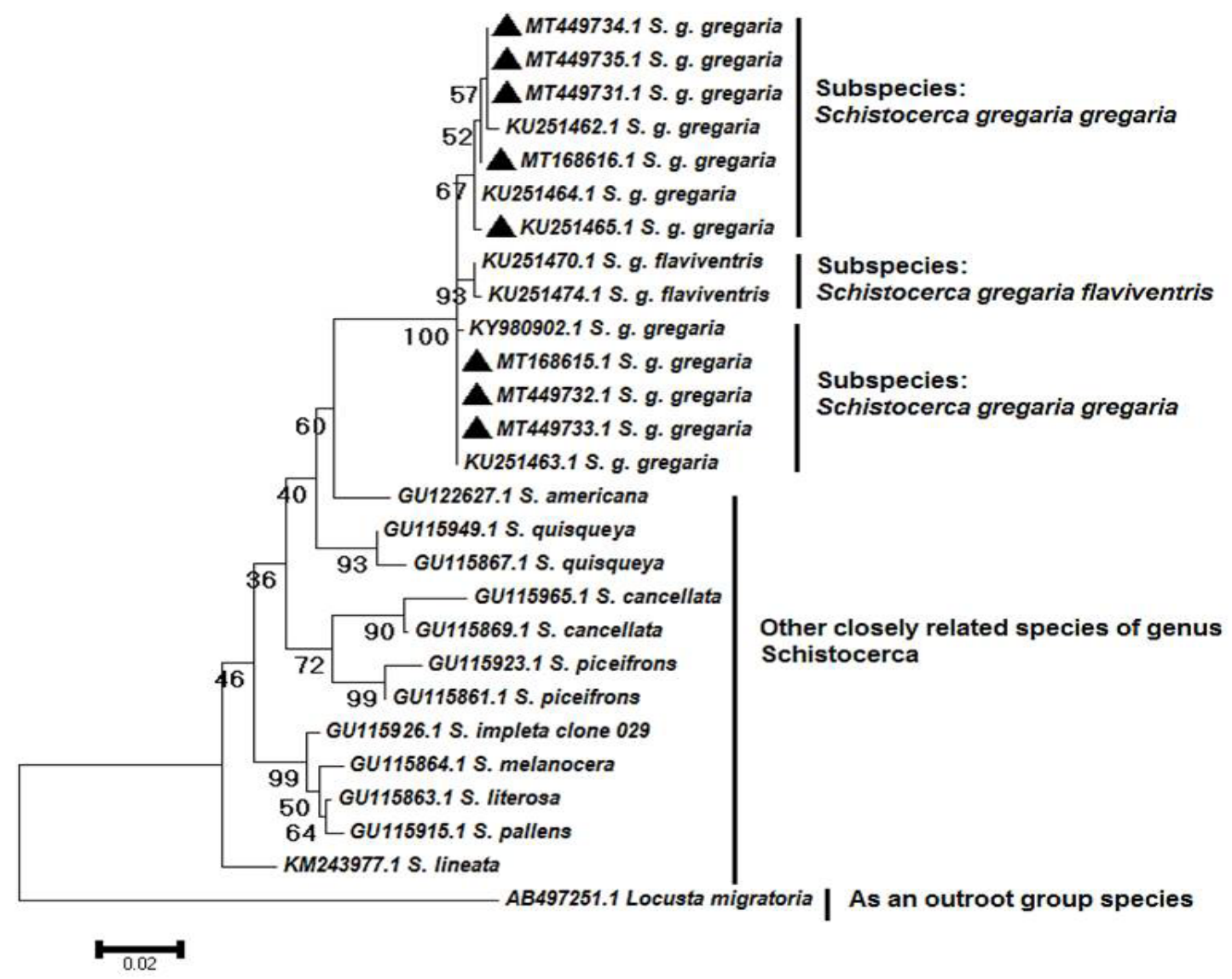

Fig. 2. Molecular phylogenetic analysis by Maximum Likelihood Method: Phylogenetic Tree produced from 8 Pakistani DNA sequences of desert locust, S. gregaria gregaria (Triangles: NCBI submitted Accession numbers) and 19 other locust sequences based on mitochondrial Cytochrome oxidase I gene based primers.

\section{DISCUSSION}

Locusts belonging to the family Acrididae (Insecta: Orthoptera) are actually short horned grasshoppers in which solitary individuals are transformed into gregarious ones in response to increased population density having complex evolution of density dependent plasticity (Pener, 1983; Pener and Simpson, 2009; Song et al., 2017). The desert locust, Schistocerca gregaria (Orthoptera: Acrididae) distributed in various regions of Southwest Asia, Africa and Middle East are devastating agricultural pests (Meinzingen, 1993; El Hassan, 2000). Recently, in June 2019 and Jan 2020, a large swarm appeared in Pakistan from Iran and destroyed cotton, wheat, maize and other crops in various provinces of Pakistan. The samples were collected and by studying morphological characters of several specimens and molecular features of 8 DNA sequences submitted and reported from Pakistan (MK168615.1, MK168616.1, MT449731.1, MT449732.1, MT449733.1, MT449734.1, MT449735.1, KU2514651.1) showed a maximum genetic similarity (99-100\%) and minimum amino acid substitution divergence value (0.00-0.009) (Table II) to one of the most prevailed phase changing (gregarious) subspecies, $S$. gregaria gregaria originated from Northern Africa as compared to another closely related subspecies, $S$. gregaria flaviventris found in Southern part of Africa (Popov et al., 1991; Chapuis et al., 2017). Schistocerca gregaria also named as Schistocerca americana with their same subspecies but Schistocerca gregaria is acceptable by majority of molecular taxonomist. Four species among the 50 species of the genus Schistocerca, S. gregaria, S. piceifrons, $S$. cancellata and $S$. interrita form huge swarms in Central and South America, Africa, Middle East and South Asia (Song and Wenzel, 2008; Song et al., 2017). Figure 2 revealed the association of desert locust of Pakistan $(S$. g. gregaria) with same subspecies reported from Algeria, Niger and Mauritania by placing in one cluster of the phylogenetic tree as compared to $S$. g. flaviventris of Tanzania (Tan6) and Namibia (Nam1) present in Southern 
Africa as well as other closely related Schistocerca species of Central and Southern America. Similarly, a clear distinct single monophyletic clade was formed with $S$. g. flaviventris mtDNA sequences as observed in current study within the desert locust lineage (Chapuis et al., 2016). The current molecular study of subspecies determination was confirmed by several researchers using COI gene (de Waard et al., 2010; Mousseau and Sikes, 2011; Silva-Brandão et al., 2013; Chapuis et al., 2016). A distinct morphological character between two sub species of desert locust (S. g. gregaria and $S$. g. flaviventris) is the elongated and un bend cercus of male $S$. g. gregaria which was observed in current study as compared to short and wider cercus observed in male of $S$. g. flaviventris (Song, 2004, 2009). The studied subspecies (S. g. gregaria) has much breeding potential as compared to other subspecies (S. $g$. faviventris) because of the distinctive shape and elongated length of male cercus that give advantage during mating. The color variation observed on the head, thorax and abdomen of sexually matured males and females of S. g. gregaria have also been reported by the previous researchers (Maeno and Tanaka, 2007; Tanka et al., 2010; Nishide and Tanaka, 2010). Central American locust ( $S$. piceifrons) with two subspecies; $S$. p. piceifrons and $S$. p. peruviana (Harvey, 1983; and South American locust (S. cancellata) (Barrientos Lozano et al., 1992) showed genetic similarity (93-95\%) with $S$. g. gregaria reported from Pakistan. The desert locust of Pakistan (. g. gregaria) has a wide genetic differentiation from other widely spread migratory locust (Locusta migratoria) which further consist of two subspecies as Asian Migratory Locust (flying capacity $1000 \mathrm{~km}$ (L. migratoria migratoria) and African Migratory Locust, (L. migratoria migratorioides) (Linnaeus, 1758) (Ma et al., 2012; Stige et al., 2007; Tian et al., 2011).

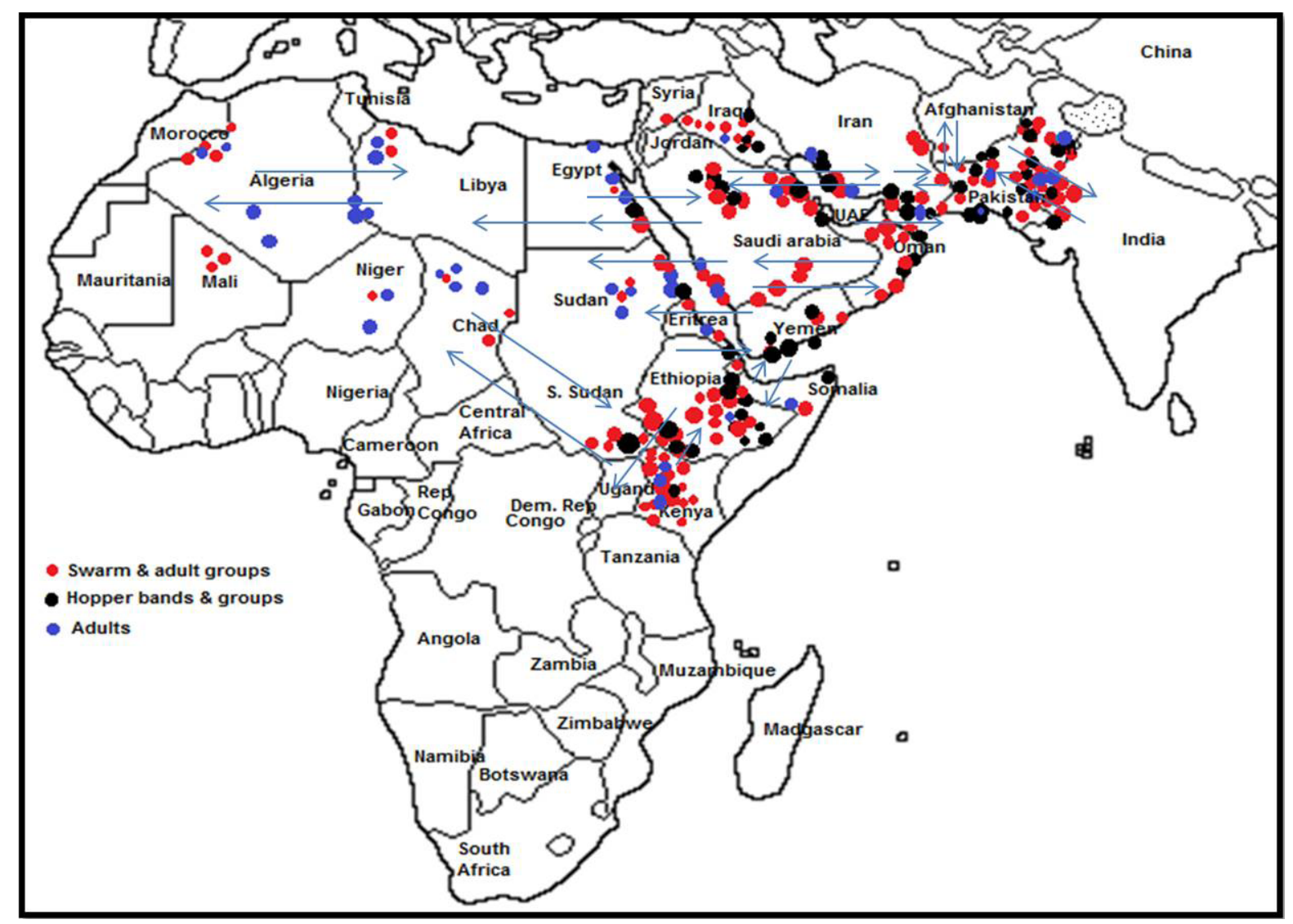

Fig. 3. The locations of desert locusts (S. gregaria) found in Southern and Eastern Africa towards Asia through gulf countries in Pakistan developed during 2018-2020. Arrows show the expected potential alternate routes of desert locust, S. g. gregaria, a gregarious subspecies recently found in Pakistan (2019-2020 locust attack) and originated in Northern Africa (Sahara Desert). One potential route is from Sahara desert through Arabian Desert (Saudi Arabia and Iraq) to Iran and Pakistan. $2^{\text {nd }}$ is from Sahara desert (Sudan) and Eastern Africa (Kenya, Ethiopia, Somalia) through Yemen, Oman and Saudi Arabia to Iran/India and Pakistan. Potential threat of locust entrance from neighboring countries (Iran, India and Afghanistan) is highlighted. 
In current research, identification of subspecies of desert locusts and their association with same subspecies which is widely present in Northern and now in East Africa suggested few routes (migration pattern) of its entrance and exit from Africa towards Asia (Fig. 3). The gregarious subspecies (S. g. gregaria) was originated from Northern Africa (Sahara desert) and mostly prevailed in Northern and Eastern part of Africa. The other closely related solitary subspecies ( $S$. g. flaviventris) was found only in Southern Part of Africa. Therefore, it is further suggested that $S$. g. gregaria present in Pakistan during 2019-2020 swarms has a strong association with Sahara desert of Algeria, Niger, Egypt and Sudan as well as Eastern part of Africa (Somalia, Kenya and Ethiopia) from where this species was potentially reproduced (2018-2020) due to favorable climatic condition and migrated to different countries (Fig. 3).

Pakistan is an important front-line country for locust attack because of the presence of transit zones and potential breeding areas present in Indus Valley of Pakistan, particularly winter/spring breeding areas of Baluchistan (Lasbela/Uthal area), Sindh (West Karachi) and summer breeding zones of Sindh (Thar) and Southern Punjab (Cholistan, Thal etc.). Internal and external developing locust swarm move between these areas for seasonal breeding and destroy crops in different provinces along with few districts of Khyber Pakhtunkhwa (KPK). In June 2019, swarm of desert locust entered from neighboring countries (Iran and India) and hundreds of hectare of important crops costing millions was lost in this attack. Large population of desert locust ( $S$. g. grearia) appeared again in early-2020 to Mid-2020 from various summer breeding areas of Pakistan and again damaging cotton, sugarcane, maize, fruit crops and vegetables in different provinces of Pakistan. Due to desert locust attack, a loss of $\$ 2.2$ billion for winter crop (wheat/potatoes) and $\$ 4.6$ billion for summer crops in a year has been estimated by the Food and Agriculture organization (FAO) of United Nation. Government of Pakistan has declared national emergency since Jan 2020 in the country to counter swarms attack and to adopt proper control measures. According to a report, 38\% area of Pakistan $(65 \%$ area of Baluchistan, 26\% Sindh, 15\% Punjab and several districts of KPK are under severe threat by desert locust (Schistocerca gregaria). In May, 2020 locust was widely reported from 56 districts including 17 districts of Punjab with devastating effect on cotton in South Punjab. Current breeding and widely presence of locust in India (Rajasthan) and Iran can be fatal to main crops if its migration towards Pakistan not observed properly in Pakistan. End of April, 2020 Chinese Government helped Pakistan by providing 300 tons of ULV malathian, 50000 liter of Lambda cyhalothrin and 50 vehicle mounted high efficiency sprayers to fight against locust disaster. National Locust Control Centre (NLCC), National Disaster Management Authority (NDMA), Ministry of Food, Plant Protection, and Agriculture Extension departments are using these facilities to control desert locust. Thousands of acres (121605 hectare) have been sprayed and more than 3682639 hectare under surveillance. Pakistan has deployed more than 1100 surveys and control teams across the country.

Potential migratory routes and breeding places for desert locust migration from Southern and Eastern Africa to Pakistan through gulf countries (Yemen, Oman, UAE and Saudi Arabia) have been elaborated (Fig. 3). Small to large groups and swarms of locusts are developing in spring breeding areas in Africa, gulf region as well as in southern coast and parts of Iran (Sistan-Baluchistan) as vegetation is drying out. These locust groups and swarms will move east to the Indo-Pakistan summer breeding areas of Sindh and Punjab. Control operations are underway but same pattern for $S$. g. flaviventris and other species can't be ignored from other contries towards Pakistan. It is expected that swarm may last for next year 2021 and create trouble if not controlled properly. So, it is essential to protect crops from external as well as internal threat of locust by careful monitoring of eggs in breeding zones. Hundreds of eggs $(\sim 300)$ are laid by single female of desert locust at 3-10 $\mathrm{mm}$ depth by inserting their abdomen in sandy soils. It is therefore utmost important to observe all seasons breeding areas of desert locust, $S$. g. gregaria to destroy their eggs and emerging young ones through chemical, biological, physical, cultural and mechanical ways. After hatching, young ones before going to fledgling stage (before wing formation) can be easily controlled with insecticides (malathion, lambda cyhalothrin, fipronil etc.) and bio pesticides (Metarhizuium anisoplae var acridum) or drenching methodology. After, wing formation, serotonin is produced in nervous system and guaiacol in gut of insect therefore locust body color is changed, food consumption increased, mating enhanced, quickly reproduced and under overcrowding condition, locust swarm occurs and move along wind direction and by using olfactory sense find food and vegetation. Desert locust, $S$. g. gregaria can fly easily $150 \mathrm{~km} /$ day and approximately 150 million of desert locusts are present in $1 \mathrm{~km}^{2}$ area of a small swarm that can eat up to 35000 human's equal food in a day. Drum beating, smoke making and irrigation can be helpful to stop locust settling in the fields that can be achieved by active involvement of farmer's community. Identification and utilization of species specific indigenous entomopathogens (fungi, bacteria, viruses, and nematodes), predators and parasitoids, phytochemicals, development of low cost efficient machinery, nanoparticle 
based insecticides and RNA interference (RNAi) based important GM crops will be best strategy to control locust and reduce environmental pollution caused by pesticides. Locusts are rich in protein and can be utilized as protein rich diet for human, poultry and fish. Relevant industries can be engaged for getting maximum benefit from it. Sustainable management of desert locust is possible only along with other control practices, if deserts (breeding areas) of Pakistan are converted into green areas. Recently, billion tree project initiated by Government of Pakistan can be useful to convert deserts into greenery.

The precise identification of desert locust $(S . g$. gregaria) will be very helpful to adopt species specific control measures (biological control) not only in Pakistan but also in foreign countries. Further, keeping in view the potential entrance routes of locusts from Africa, gulf and neighboring countries (India, Iran, and Afghanistan), existence of other potentially damaging species of locust, particularly $S$. g. flaviventris can't be ignored in Pakistan. The study on molecular taxonomy, host plant preference, phytochemical and bio pesticides synthesis, insecticides toxicity and resistance against desert locust, $S$. g. gregaria is under progress.

\section{CONCLUSION}

The identification of a sub-species of desert locust S. g. gregaria (Forskål, 1775) from Pakistan using the mitochondrial Cytochrome C Oxidase subunit 1 (COI) confirmed the database search that the sequenced DNA segment is corresponded to the most prevailed species of desert locust (Schistocerca gregaria subspecies gregaria) reported from Northern Africa. Further, this is the first report of molecular identification $S$. g. gregaria with observed adult morphological parameters and migratory pattern with potential routes of locust entrance and exit from Northern and Eastern Africa towards Asia particularly from neighbor countries to Pakistan. Regular seasonal monitoring of desert locust (egg laying and destroying) in breeding and infested areas will be helpful to manage this pest.

\section{ACKNOWLEDGEMENTS}

Authors are thankful to Higher Education commission of Pakistan (HEC) (Grant No. 204535/NRPU/R\&D/ HEC/14/159 and Pak-Norway Institutional Cooperation Program for providing funds to JNA and SJNA for research and to establish research Laboratory (IGCDB) at University of Agriculture Faisalabad, Pakistan.

\section{Statement of conflict of interest}

Authors declare that they have no conflict of interest.

\section{REFERENCES}

Ahmad, J.N., Ahmad, S.J.N., Ahmad, M.A., Contaldo, N., Paltrinieri, S. and Bertaccini, A.A., 2017. Molecular and biologic characterization of a phytoplasma associated with Brassica campestris phyllody disease in Punjab province. Eur. J. Pl. Pathol., 149: 117-125. https://doi.org/10.1007/ s10658-017-1170-4

Ahmad, S., Cheema, H.M.N., Khan, A.A., Khan, S.A. and Ahmad, J.N., 2019. Resistance status of Helicoverpa armigera against Bt cotton in Pakistan. Transg. Res., 28: 199-212. https://doi.org/10.1007/ s11248-019-00114-9

Ayali, A., 2019. The puzzle of locust density-dependent phase polyphenism. Curr. Opin. Insect Sci., 35: 4147. https://doi.org/10.1016/j.cois.2019.06.008

Barrientos, L.L., Astacio, C.O., Alvarez, B.F. and Poot, M.O., 1992. Manual técnico sobre la langosta voladora (Schistocerca piceifrons piceifrons Walker, 1870) y otros Acridoideos de Centro América y Sureste de México. FAO, San Salvador (El Salvador) OIRSA, San Salvador El Salvador.

Chapuis, M.P., Foucart, A., Plantamp, C., Blondin, L., Leménager, N., Benoit, L., Gay, P.E. and Bazelet, C.S., 2017. Genetic and morphological variation in non-polyphenic Southern African populations of the desert locust. Afr. Entomol., 25: 13-23. https:// doi.org/10.4001/003.025.0013

Chapuis, M.P., Bazelet, C.S., Blondin, L., Foucart, A., Vitalis, R. and Samways, M.J., 2016. Subspecific taxonomy of the desert locust, Schistocerca gregaria (Orthoptera: Acrididae), based on molecular and morphological characters. Syst. Ent., 41: 516-530. https://doi.org/10.1111/syen.12171

Cheseto, X., Kuate, S.P., Tchouassi, D.P., Ndungu, M., Teal, P.E. and Torto, B., 2015. Potential of the desert locust Schistocerca gregaria (Rthoptera: Acrididae) as an unconventional source of dietary and therapeutic sterols. PLoS One, 10: 1-13. https:// doi.org/10.1371/journal.pone.0127171

De Waard, J.R., Mitchell, A. and Keena, M.A., 2010. Towards a global barcode library for Lymantria (Lepidoptera: Lymantriinae) tussock moths of biosecurity concern. PLoS One, 5: 1-10. https://doi. org/10.1371/journal.pone.0014280

El Hassan, I.M., 2000. The effect of Metarhizium anisopliae var. acridium (Metch) sorkin conjunction with the adults' gregarizatation pheromones on the gregarious nymphs of Schistocerca gregaria (Forskal1773). M.Sc. Agric., pp. 109.

FAO, 2020. Commission for controlling the desert locust 
in South-West Asia (SWAC). Available at: http:// www.fao.org/ag/locusts/swac/countries/pakistan/ en/ (Accessed on 18 August, 2020).

Farrow, R.A., 1979. Causes of recent changes in the distribution and abundance of the migratory locust (Locusta migratoria L.) in Australia in relation to plagues. Division of Entymology, The Commonwealth Scientific and Industrial Research Organization, Canberra, Australia, pp. 32-41.

Folmer, O., Black, M., Hoeh, W., Lutz, R. andVrijenhoek, R., 1994. DNA primers for amplification of mitochondrial cytochrome c oxidase subunit I from diverse metazoan invertebrates. Mol. Mar. Biol. Biotechnol., 3: 294-299.

Granados, F., 2011. Las plagas de langosta en el área maya: ambiente e historia de una calamidad en la época prehispánica. Península, 6: 27-46.

Gastón, J., 1969. Sintesis historica de la Langosta en la Argentina. Secretaría de Estado de Agricultura y Ganadería.

Harvey, A.W., 1981. A reclassification of the Schistocerca americana complex (Orthoptera: Acrididae). Acrida, 10: 61-77.

Harvey, A.W., 1983. Schistocerca piceifrons (Walker) (Orthoptera: Acrididae), the swarming locust of tropical America: A review. Bull. entomol. Res., 73: 171-184. https://doi.org/10.1017/ S0007485300008786

Lovejoy, N.R., Mullen, S.P., Sword, G.A., Chapman, R.F. and Harrison, R.G., 2006. Ancient transAtlantic flight explains locust biogeography: Molecular phylogenetics of Schistocerca. Proc. $R$. Soc. B. Sci., 273: 767-774. https://doi.org/10.1098/ rspb.2005.3381

Latchininsky, A.V., 2013. Locusts and remote sensing: A review. J. appl. Remote Sensing, 7: 075099. https://doi.org/10.1117/1.JRS.7.075099

Manzoor, M., Ahmad, J.N., Ahmad, S.J.N., Naqvi, S.A., Rasheed, R., Umar, U. and Haider, M.S., 2020. Population dynamics, abundance and infestation of red palm weevil, Rhynchophorus ferrugineus (Oliver) in different geological regions of date palm in Pakistan. Pak. J. agric. Sci., 57: 381-391.

Manzoor, M., Ahmad, J.N., Giblin-Davis, R.M. and Rafael, G.R., 2018. Molecular identification and phylogenetic analysis of distinct geographical populations of Rhynchophorus ferrugineus (Olivier) (Coleoptera: Curculionidae) in Pakistan. Int. J. Agric. Biol., 20: 1997-2004.

Maeno, K. and Tanaka, S., 2007. Morphological and behavioural characteristics of a gynandromorph of the desert locust, Schistocerca gregaria. Physiol.
Ent., 32: 294-299. https://doi.org/10.1111/j.13653032.2007.00573.x

Meinzingen, W.F. (ed.), 1993. A guide to migrant pest management in Africa. FAO, Rome.

Mousseau, T. and Sikes, D.S., 2011. Almost but not quite a subspecies: A case of genetic but not morphological diagnosability in Nicrophorus (Coleoptera: Silphidae). Biol. J. Linn. Soc., 102: 311-333. https://doi.org/10.1111/j.10958312.2010.01568.x

Ma, C., Yang, P., Jiang, F., Chapuis, M.P., Shali, Y. and Sword, G.A., 2012. Mitochondrial genomes reveal the global phylogeography and dispersal routes of the migratory locust. Mol. Ecol., 21: 4344-4358. https://doi.org/10.1111/j.1365-294X.2012.05684.x

Nishide, Y. and Tanaka, S., 2012. Yellowing, morphology and behaviour in sexually mature gynandromorphs of the desert locust Schistocerca gregaria. Physiol. Ent., 37: 379-383. https://doi.org/10.1111/j.13653032.2012.00854.x

Popov, G.B., Duranton, J.F. and Gigault, J., 1991. Etude Écologique des Biotopes du Criquet Pèlerin\# Schistocerca gregaria (Forskal, 1775) en Afrique Nord-Occidentale: Mise en Évidence et Description des Unités Territoriales Écologiquement Homogènes. CIRAD-PRIFAS.

Pener, M.P., 1983. Endocrinology of insects. In: Invertebrate endocrinology (eds. R.G.H. Downer and H. Laufer), Vol. 1. Alan R. Liss, Inc., pp. 379-394. https://doi.org/10.1016/0014-5793(84)80892-3

Pener, M.P., 1991. Locust phase polymorphism and its endocrine relations. Adv. Insect Physiol., 23: 1-79. https://doi.org/10.1016/S0065-2806(08)60091-0

Pener, M.P. and Simpson, S.J., 2009. Locust phase polyphenism: An update. Adv. Insect Physiol., 36: $1-286$. https://doi.org/10.1016/S00652806(08)36001-9

Pener, M.P. and Yerushalmi, Y., 1998. The physiology of locust phase polymorphism: An update. J. Insect Physiol., 44: 365-377. https://doi.org/10.1016/ S0022-1910(97)00169-8

Sharif, M.Z., Ahmad, S.J.N., Tahir, M., Ziaf, K., Zhang, S.H. and Ahmad, J.N., 2019. Molecular identification and characterisation of phytoplasma associated with carrot, cabbage and onion crop and their putative insect vectors in Punjab, Pakistan. Pak. J. agric. Sci., 56: 407-414.

Silva-Brandão, K.L., Almeida, L.C., Moraes, S.S. and Cônsoli, F.L., 2013. Using population genetic methods to identify the origin of an invasive population and to diagnose cryptic subspecies of Telchin licus (Lepidoptera: Castniidae). Bull. 
entomol. Res., 103: 89-97. https://doi.org/10.1017/ S0007485312000430

Song, H., 2004. On the origin of the desert locust Schistocerca gregaria (Forskal) (Orthoptera: Acrididae: Cyrtacanthacridinae). Proc. R. Soc. Lond. Ser. B: Biol. Sci., 271: 1641-1648. https://doi. org/10.1098/rspb.2004.2758

Song, H. and Wenzel, J.W., 2008. Phylogeny of birdgrasshopper subfamily Cyrtacanthacridinae (Orthoptera: Acrididae) and the evolution of locust phase polyphenism. Cladistics, 24: 515-542. https://doi.org/10.1111/j.1096-0031.2007.00190.x

Song, H., 2009. Species-specificity of male genitalia is characterized by shape, size, and complexity. Insect Syst. Evol., 40: 159-170. https://doi. org/10.1163/187631209X424571

Song, H., Foquet, B., Mariño-Pérez, R. and Woller, D.A., 2017. Phylogeny of locusts and grasshoppers reveals complex evolution of density-dependent phenotypic plasticity. Scient. Rep., 7: 1-13. https:// doi.org/10.1038/s41598-017-07105-y

Stige, L.C., Chan, K.S., Zhang, Z., Frank, D. and Stenseth, N.C., 2007. Thousand-year-long Chinese time series reveals climatic forcing of decadal locust dynamics. Proc. natl. Acad. Sci. U.S.A., 104: 16188-16193. https://doi.org/10.1073/ pnas.0706813104

Tamura, K., Stecher, G., Petersony, D., Filipski, A. and
Kumar, K., 2013. MEGA6: Molecular evolutionary genetics analysis version 6.0. Mol. Bio. Evol., 30: 2725-2729.

Tanaka, S., 2006. Corazonin and locust phase polyphenism. Appl. Ent. Zool., 41: 179-193. https:// doi.org/10.1303/aez.2006.179

Tanaka, S., Maeno, K., Mohamed, K., Ely, S.O. and Eby, M.A.B., 2010. Upsurges of desert locust populations in Mauritania: Body coloration, behavior and morphological characteristics. Appl. Ent. Zool., 45: 641-652. https://doi.org/10.1303/ aez.2010.641

Tian, H., Stige, L.C., Cazelles, B., Kausrud, K.L., Svarverud, R. and Stenseth, N.C., 2011. Reconstruction of a 1,910-y-long locust series reveals consistent associations with climate fluctuations in China. Proc. natl. Acad. Sci. U.S.A., 108: 14521-14526. https://doi.org/10.1073/ pnas.1100189108

Uvarov, B.P., 1977. Grasshoppers and locusts, Vol. 2. Centre for Overseas Pest Research, London.

Zuckerkandl, E. and Pauling, L., 1965. Evolutionary divergence and convergence in proteins. In: Evolving genes and proteins (eds. V. Bryson and H.J. Vogel). Academic Press, New York, pp. 97166. https://doi.org/10.1016/B978-1-4832-27344.50017-6 